\title{
Anti-inflammatory effect of foods and crude drugs in relation to bitter and spicy tastes
}

\author{
Yukinobu Ikeya', Denise A. Epp ${ }^{2}$, and Mikio Nishizawa ${ }^{3}$
}

\begin{abstract}
${ }^{1}$ Department of Pharmacy Educational Assist Center, Daiich University of Pharmacy, Minamiku, Fukuoka, 815-8511, Japan; ${ }^{2}$ Center for Advancing Pharmaceutical Education, Daiichi University of Pharmacy, Fukuoka, 815-8511, Japan; ${ }^{3}$ Department of Biomedical Sciences, College of Life Sciences, Ritsumeikan University, Kusatsu, Shiga, 525-8577, Japan
\end{abstract}

Corresponding author: Yukinobu Ikeya, Ph.D., Department of Pharmacy Educational Assist Center, Daiich University of Pharmacy, Minami-ku, Fukuoka, 815-8511, Japan.

Submission Date: October $21^{\text {st }}$, 2018, Acceptance Date: March $28^{\text {th }}$, 2019, Publication Date: March 31 ${ }^{\text {st }}, 2019$

Citation: Ikeya Y., Epp D.A., Nishizawa M. Anti-inflammatory effect of foods and crude drugs in relation to bitter and spicy tastes. Bioactive Compounds in Health and Disease 2019; 2(4): 77 93. https://doi.org/10.31989/bchd.v2i4.613

\begin{abstract}
In Kampo medicine as well as traditional Chinese medicine, each crude drug is classified by four properties (cold, cool, warm, and heat), five tastes (sour, bitter, sweet, spice, and salt) based on the Yin-yang and five elements (wood, fire, earth, metal, water) theory. The four properties and five tastes are greatly related to the medicinal efficacy of the crude drug in Kampo medicine. The pharmacological function of crude drugs is called "Yakuno" in Japanese. Examples of Yakuno include various functions such as clearing heat and removing blood stasis. Crude drugs with properties classified as cold or cool have the function to clear heat as they cool the body. Crude drugs classified as bBitter also have the function to clear heat. We speculated that antiinflammatory constituents are included in crude drugs and food that are classified as cold or cool in property and bitter in taste.

The suppression of nitric oxide (NO) production, which is a pro-inflammatory mediator, is correlated with the anti-inflammatory activity of drugs. Therefore, studies of anti-inflammatory constituents have been conducted with the suppressive effect of NO production in primary
\end{abstract}


cultured hepatocytes as an indicator. Each extract or constituent was added to the medium, and NO levels in the medium were assayed by Griess method.

The constituents that suppressed NO production in the hepatocytes were isolated from crude drugs with cold or cool property, such as coptis rhizome, phellodendron bark, lonicera flower, and cherry bark. Other groups isolated the NO-suppressing constituents from crude drugs with cold or cool property, such as scutellaria root, gardenia fruit, and mountain kidney. Next, we isolated the NO-suppressing constituents from the crude drugs or foods with bitter taste: Coptis Rhizome, phellodendron Bark, and Asparagus officinalis stem. Other NO-suppressing constituents were also isolated from crude drugs and foods with Bitter taste: Atractylodes Lancea Rhizome, Moutan Bark, fruit of Momordica charantia, Rhizome of Curcuma longa, Leaf of Camellia sinensis, and chrysanthemum flower. Based on these studies, crude drugs and foods with cold or cool property and those with bitter taste, may possess anti-inflammatory effects. Furthermore, many pungent constituents from foods have been reported to have an antiinflammatory effect. Therefore, in studying anti-inflammatory constituents of foods and crude drugs, it seems that information on whether those properties are cold or cool and whether those tastes are bitter or spicy is useful.

Keywords: crude drug, Kampo medicine, food, property, taste, nitric oxide, inflammation, pharmacological function

\section{INTRODUCTION}

The medicine for treating diseases using plant-based natural products that was born in ancient China is called traditional Chinese medicine. A medicine using natural products developed in Japan and is also based on traditional Chinese medicine is called Kampo medicine. Kampo medicine developed independently from traditional Chinese medicine in the 18th century, and both are founded on the idea that medicine and food are of the same origin. The oldest medical book in China, Huangdi Neijing (Koutei Daikei in Japanese), states that five grains, five livestock, five vegetables and five fruit describe "food" when used to satisfy hunger and "medicine" when used to heal diseases, confirming the commonality of natural product medicine and food [1]. In the Japanese Pharmacopoeia, "crude drugs" are defined as medicinal parts, cell contents, secretions and extracts of plants and animals, or minerals. Kampo medicine is composed of crude drugs mainly from specific parts of plants, but also from animals and minerals. The efficacy of Kampo medicine depends on the property and pharmacological function of each blended crude drug.

The basic theory of Kampo and other Oriental medicine is the yin-yang and five elements theory. The yin-yang theory is the idea of classifying everything in the universe into two 
categories of yin and yang. For example, passive, deficiency, cold, and interior are classified as yin. In contrast, active, excess, heat, and exterior are classified as yang. The five elements theory explains the change in the natural world by the function of five basic elements (wood, fire, earth, metal, and water) [2]. It is explained that all things in the natural world are made up of five elements. Seasons, viscera, and tastes are divided into five seasons, five organs, five tastes and each corresponds to five elements. Five seasons, five viscera, and five tastes are also closely tied to five elements. (Table 1) The crude drug enters the body through a channel tropism that affects the five viscera (liver, heart, spleen, lung, and kidney) and six bowels (gall bladder, small intestine, stomach, large intestine, bladder, and triple energizer regions). In Kampo medicine, diseases are thought to be an imbalance between yin and yang or an imbalance among the five elements.

Table 1. Relationship of the five elements with tastes, viscera, and seasons.

\begin{tabular}{|l|l|l|l|l|}
\hline $\begin{array}{c}\text { Five } \\
\text { elements }\end{array}$ & Five tastes & \multicolumn{1}{c|}{$\begin{array}{c}\text { Five } \\
\text { viscera }\end{array}$} & Five seasons & Application \\
\hline Wood & Sour & Liver & Spring & $\begin{array}{l}\text { Eat sour food to refresh } \\
\text { because the liver is disturbed } \\
\text { in spring }\end{array}$ \\
Fire & Bitter & Heart & Summer & $\begin{array}{l}\text { Eat bitter food to calm a } \\
\text { weak heart in summer }\end{array}$ \\
Metal & Sweet & Spleen & $\begin{array}{l}\text { Hottest } \\
\text { period of } \\
\text { summer }\end{array}$ & $\begin{array}{l}\text { Eat sweet food because the } \\
\text { spleen gets tired in the } \\
\text { hottest period of summer }\end{array}$ \\
Water & Salty & Lung & Autumn & $\begin{array}{l}\text { Eat spicy food to recover } \\
\text { weak lung in autumn }\end{array}$ \\
& Kidney & Winter & $\begin{array}{l}\text { Eat salty food to feed a weak } \\
\text { kidney in winter }\end{array}$ \\
\hline
\end{tabular}

Each crude drug is classified by four properties (cold, cool, warm, and heat), five tastes (sour, bitter, sweet, spice, and salt) based on the Yin-yang, and the Five elements theory. Four properties and five tastes are greatly related to pharmacological function of the crude drug in Kampo medicine. The pharmacological function of crude drugs is called "Yakuno" in Japanese.

Based on the Yin-yang theory, each food and crude drug is classified into four properties of "cold, cool, warm, and heat". Cold and cool foods and crude drugs have a function of clearing heat to cool the body's heat. Warm and heat foods and crude drugs clear the body's coldness and enhance metabolism. Also, there are neutral foods and crude drugs that do not belong to either cold, cool, warm, or heat. Plane is regarded as independent from these four properties.

Each herbal medicine has pharmacological functions of Yakuno in Kampo medicine. Some examples of pharmacological functions (Yakuno) are as follows: resolving exterior (Gehyou), 
clearing heat (Seinetu), resolving blood stasis (promoting of blood circulation; Ku-oketu), replenishing blood (improvement of blood deficiency; Hoketu), reinforcing qi (improvement of qi-deficiency; Hoki), regulating qi-flowing (improvement of qi-stagnation; Riki in Japanese), lowering qi-counterflow (Kouki), circulating fluid retention (Risui).

Crude drugs with bitter taste can also clear heat. We speculated that anti-inflammatory constituents are included in the crude drugs and foods with cold or cool properties or with bitter taste. In general, the suppression of the production of the pro-inflammatory mediator, nitric oxide (NO) is correlated with the anti-inflammatory activity of a drug. Therefore, we aimed to experimentally prove that anti-inflammatory constituents are contained in crude drugs and foods with cold or cool properties, or those with bitter taste by measuring the inhibitory effect on NO production as an indicator.

\section{RESULTS AND DISCUSSION}

\section{Anti-inflammatory constituents in the crude drugs with Cold or Cool property}

The pharmacological function of clearing heat is the anti-inflammatory effect and antipyretic effect in modern medicine [3]. A drug to clear heat is a drug that removes inflammation and cools the heat of the body with the property of cold or cool [3]. Therefore, we decided to study the antiinflammatory constituents of crude drugs and foods, which have the properties of cold or cool. Anti-inflammatory effects were examined using cultured hepatocytes by monitoring the effect on NO production, as previously described $[4,5]$.

Studies were conducted on the inhibitory activity of NO production and its suppressive constituents of coptidis rhizome, phellodendron bark, lonicera flower and cherry bark with cold or cool properties. Coptidis rhizome is the rhizome of Coptis japonica Makino, C. chinensis Franchet, $C$. deltoidea C.Y. Cheng et Hsiano, or C. teeta Wallich (Ranunculaceae) . It has cold property, bitter taste, and clears heat [3]. Methanolic extract of coptidis rhizome based on the rhizome of $C$. chinensis franchet and its constituent berberine showed marked inhibition of NO production [7]. Phellodendron Bark is the bark of Phellodendron amurense Ruprecht or P. chinense Schneider (Rutaceae). phellodendron bark also has cold property, bitter taste, and clears heat [3]. Methanolic extract of phellodendron bark based on the rhizome of $P$. amurense Ruprecht and its constituents, berberine, limonin, and obakunone showed marked inhibition of NO production [7].

Lonicera flower is the bud of Lonicera japonica Thunberg (Caprifoliacea). Lonicera flower has cold property, sweet taste, and clears heat [3]. Methanolic extract of lonicera flower and its constituent chlorogenic acid showed marked inhibition of NO production [8]. Cherry bark is the 
bark of Prunus jamasakura Siebold ex Koidzumi or P. verecunda Koehne (Rosaceae). It shows cool property, sweet taste, and the pharmacological function is antitussive and removing phlegm. Methanolic extract of the bark of $P$. jamasakura Siebold ex Koidzumi and its constituents, sakuranetin and naringenin showed marked inhibition of NO production [9]. Several antiinflammatory components in crude drugs with cold or cool property have been reported. Huang et al. and Chen et al. reported that baicalin, baicalein, wogonin, oroxylin A (flavonoids) are antiinflammatory constituents of Scutellaria Root $[10,11]$. Ko et al. and Hong et al. reported that genipin (iridoid) and crocetin (carotenoid) are anti-inflammatory constituents of gardenia fruit $[12,13]$. In these examples, anti-inflammatory constituents are found from many crude drugs with cold and cool properties (Figure 1).

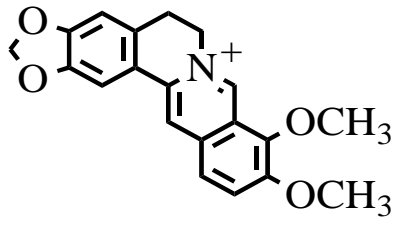

Berberine

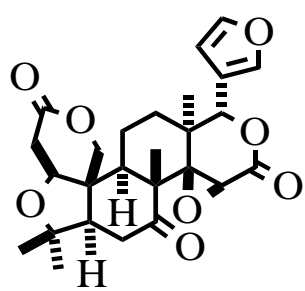

Limonin

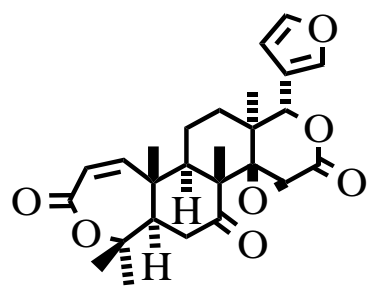

Obakunone<smiles>O=C(O)O[C@H]1C[C@H](O)[C@@H](O)[C@H](O)C1</smiles>

Chlorogenic acid<smiles>COc1cc(O)c2c(c1)O[C@H](c1ccc(O)cc1)CC2=O</smiles>

Sakuranetin<smiles>O=C1C[C@H](c2ccc(O)cc2)Oc2cc(O)cc(O)c21</smiles>

Naringenin

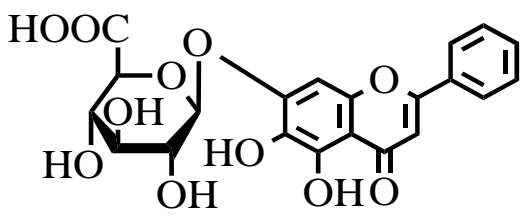

Baicalin<smiles>O=c1cc(-c2ccccc2)oc2cc(O)c(O)c(O)c12</smiles>

Baicalein<smiles>COC(=O)[C@H]1C[C@H]2C=C[C@@H]1[C@H](O)O[C@H]2O</smiles>

Genipin<smiles>CC(=C/C=C(C)/C=C/C=C(C)/C=C/C=C/C(C)=C/C=C/C(C)=C/C=C/C(C)=C/C(=O)O)C(=O)O</smiles>

Crocetin

Figure 1. NO-suppressing constituents in the crude drugs with cold or cool property. Sakuranetin, baicalin, and baicalein (flavonoids), chlorogenic acid (phenyl propanoid), limonin and obakunone (limonoids), genipin (iridoid), and crocetin (carotenoid) are shown. 
Table 2. Relation between tastes and main pharmacological functions in Kampo medicine

\begin{tabular}{|lll|}
\hline Five taste & Five viscera & \multicolumn{1}{c|}{ Pharmacological function (Yakuno) } \\
\hline Sour & Liver & Converging (Shyuren), Consolidating (Kojyu) \\
Bitter & Heart & Clearing heat (Seinetsu), Sadating (Chinsei) \\
Sweet & Spleen & Tonifying qi (Hoki), Harmonizing the center (Wachu) \\
Spicy & Lung & Dispersing (Hassan), Resolving the exterior (Gehyo) \\
Salty & Kidney & Soften (Nanken), Promoting defecation (Syage) \\
Bland* & & Removing dampness and promoting diuresis (Risui-Shinsitsu) \\
\hline
\end{tabular}

*lacks flavor

\section{Anti-inflammatory constituents in the crude drugs with Bitter tastes}

As shown in Table 2, the five tastes effect on each of the corresponding five viscera have pharmacological functions in Kampo medicine. Minar et al. described that bitter taste has the effects of excretion, drying, and clearing heat-fire [14]. Therefore, bitter crude drugs and foods are considered to have an anti-inflammatory effect. Table 3 shows the main crude drugs with Bitter taste. Bitter crude drugs often have cold and cool in property.

Among bitter crude drugs in Table 3, we studied the NO-suppressing constituents of Atractylodes Lancea rhizome and moutan bark. Atractylodes Lancea Rhizome is the rhizome of Atractylodes lancea De Candolle or A. chinensis Koidzumi (Compositae). The property of Atractylodes Lancea rhizome is warm, the taste is bitter and spicy, and the pharmacological function is dispelling pathogenic wind, removing dampness, and reinforcing qi [3]. Methanolic extract of Atractylodes Lancea rhizome on the rhizome of A. chinensis Koidzumi showed marked inhibition of NO production (Y.I. and M.N., unpublished data). Xu et al. reported that $(2 E, 8 R)$ decene-4,6-diyne-1,8-diol-8-O- $\beta$-D-glucopyranoside as a constituent of Atractylodes Lancea rhizome suppress NO production [15]. Moutan bark is the root bark of Paeonia suffruticosa Andrews (Paeoniaceae). The property of moutan bark is cool, the taste is bitter and spicy, and the pharmacological function is resolving blood stasis and clearing heat [3]. Methanolic extract of moutan bark and its constituent, paeonol showed marked inhibition of NO production [16] (Figure 2).
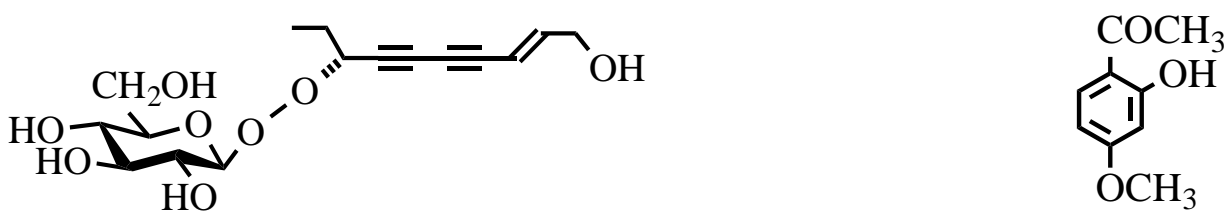

( $2 E, 8 R$ )-decene-4,6-diyne-1,8-diol-8-O- $\beta$-D-glucopyranoside

Paeonol<smiles>O=Cc1ccc(COC(=O)[C@@H]2CCC(=O)N2)o1</smiles>

(S)-Asfural<smiles>O=Cc1ccc(CO)o1</smiles>

5-Hydroxymethyl-2-furfural

Figure 2. NO-suppressing constituents in the crude drugs with bitter taste. 
Table 3. Main crude drugs with Bitter taste

\begin{tabular}{|c|c|c|c|c|c|}
\hline Crude drugs & Origin (family) & Property & Taste & $\begin{array}{l}\text { Pharmacological } \\
\text { Function }\end{array}$ & References \\
\hline $\begin{array}{l}\text { Coptis } \\
\text { Rhizome }\end{array}$ & $\begin{array}{l}\text { Rhizome of Coptis japonica } \\
\text { Makino, } \\
\text { C. chinensis Franchet, } \\
\text { C. deltoidea C.Y. Cheng et } \\
\text { Hsiano, or } \text { C. teeta } \\
\text { Wallich(Ranunculaceae) }\end{array}$ & Cold & Bitter & Clearing heat & 7 \\
\hline $\begin{array}{l}\text { Phellodendron } \\
\text { Bark }\end{array}$ & $\begin{array}{l}\text { Bark of Phellodendron amurense } \\
\text { Ruprecht or } \\
\text { P. chinense Schneider (Rutaceae) }\end{array}$ & Cold & Bitter & Clearing heat & 7 \\
\hline $\begin{array}{l}\text { Scutellaria } \\
\text { Root }\end{array}$ & $\begin{array}{l}\text { Root of Scutellaria baicalensis } \\
\text { Georgi (Labiatae) }\end{array}$ & Cold & Bitter & Clearing heat & 10,11 \\
\hline Gardenia Fruit & $\begin{array}{l}\text { Fruit of Gardenia jasminoides } \\
\text { Ellis (Rubiaceae) }\end{array}$ & Cold & Bitter & Clearing heat & 12,13 \\
\hline Moutan Bark & $\begin{array}{l}\text { Root bark of Paeonia } \\
\text { suffruticosa Andrews } \\
\text { (Paeoniaceae) }\end{array}$ & Cool & $\begin{array}{l}\text { Bitter, } \\
\text { Sour }\end{array}$ & $\begin{array}{l}\text { Clearing heat, } \\
\text { replenishing } \\
\text { blood }\end{array}$ & 16 \\
\hline $\begin{array}{l}\text { Atractylodes } \\
\text { lancea } \\
\text { Rhizome }\end{array}$ & $\begin{array}{l}\text { Rhizome of Atractylodes lancea } \\
\text { De Candolle or A. chinensis } \\
\text { Koidzumi (Compositae) }\end{array}$ & Warm & $\begin{array}{l}\text { Bitter, } \\
\text { Spicy }\end{array}$ & $\begin{array}{l}\text { Invigorating qi, } \\
\text { diuresis }\end{array}$ & 15 \\
\hline $\begin{array}{l}\text { Artemisia } \\
\text { Capillaris } \\
\text { Flower }\end{array}$ & $\begin{array}{l}\text { Leaf and branch of Artemisia } \\
\text { princeps Pampanini or } A \text {. } \\
\text { montana Pampanini } \\
\text { (Compositae) }\end{array}$ & Cool & $\begin{array}{l}\text { Bitter, } \\
\text { Spicy }\end{array}$ & $\begin{array}{l}\text { Clearing heat, } \\
\text { removing } \\
\text { dampness }\end{array}$ & \\
\hline Forsythia Fruit & $\begin{array}{l}\text { Fruit of Forsythia suspense Vahl } \\
\text { (Oleanaceae) }\end{array}$ & Cool & Bitter & $\begin{array}{l}\text { Clearing heat, } \\
\text { removing toxin }\end{array}$ & \\
\hline $\begin{array}{l}\text { Buplerum } \\
\text { Root }\end{array}$ & $\begin{array}{l}\text { Root of Buplerum falcatum L. } \\
\text { (Umbelliferae) }\end{array}$ & Cool & Bitter & $\begin{array}{l}\text { Resolving qi- } \\
\text { stagnation }\end{array}$ & \\
\hline $\begin{array}{l}\text { Anemarrhena } \\
\text { Rhizome }\end{array}$ & $\begin{array}{l}\text { Rhizome of Anemarrhena } \\
\text { asphodeloides Bunge (Liliaceae) }\end{array}$ & Cold & Bitter & Clearing heat & \\
\hline Apricot Kernel & $\begin{array}{l}\text { Seed of Prunus armeniaca Linne, } \\
\text { P. armeniaca var. ansu } \\
\text { Maximowicz, or } \\
\text { P. sibirica L.(Rosaceae) }\end{array}$ & Cold & Bitter & Expelling phlegm & \\
\hline $\begin{array}{l}\text { Japanese } \\
\text { Gentiana }\end{array}$ & $\begin{array}{l}\text { Root and rhizome of Gentiana } \\
\text { scabra Bunge, } \\
\text { G. manshurica Kitagawa, or G. } \\
\text { trifloral Pallas (Gentianaceae) }\end{array}$ & Cold & Bitter & Clearing heat & \\
\hline $\begin{array}{l}\text { Scrophularia } \\
\text { Root }\end{array}$ & $\begin{array}{l}\text { Root of Scrophularia ningpoensis } \\
\text { Hemsley or } \\
\text { S. buergeriana Miquel } \\
\text { (Scrophulariaceae) }\end{array}$ & Cool & $\begin{array}{l}\text { Bitter, } \\
\text { Salty }\end{array}$ & Clearing heat & \\
\hline Sophora Root & $\begin{array}{l}\text { Root of Sophora flavescens Aiton } \\
\text { (Legminosae) }\end{array}$ & Cold & Bitter & Clearing heat & \\
\hline
\end{tabular}


Table 4. Main foods with bitter taste

\begin{tabular}{|c|c|c|c|c|c|}
\hline Foods & Origin (family) & Taste & Property & $\begin{array}{l}\text { Pharmacological } \\
\text { function }\end{array}$ & References \\
\hline Bitter melon & $\begin{array}{l}\text { Fruit of Momordica } \\
\text { charantia L. } \\
\text { (Cucurbitaceae) }\end{array}$ & Bitter & Cold & Clearing heat & $18,19,20$ \\
\hline Asparagus & $\begin{array}{l}\text { Stem of Asparagus } \\
\text { officinalis L. (Liliaceae) }\end{array}$ & $\begin{array}{l}\text { Bitter, } \\
\text { Sweet }\end{array}$ & Cold & Clearing heat & $14,17,21$ \\
\hline Okra & $\begin{array}{l}\text { Fruit of Abelmoschus } \\
\text { esculentus Moench } \\
\text { (Malvaceae) }\end{array}$ & Bitter & Cool & $\begin{array}{l}\text { Promoting } \\
\text { defecation }\end{array}$ & \\
\hline Aloe & $\begin{array}{l}\text { Leaf meat of } \\
\text { Aloe arborescens Mill. } \\
\text { (Liliaceae) }\end{array}$ & Bitter & Cold & $\begin{array}{l}\text { Promoting } \\
\text { defecation }\end{array}$ & \\
\hline Lily bulb & $\begin{array}{l}\text { Bulb of Lilium } \\
\text { lancifolium Thunb, or } L \text {. } \\
\text { brownie F.E. Brown } \\
\text { var.colchesteri Wilson } \\
\text { (Liliaceae) }\end{array}$ & Bitter & Cool & $\begin{array}{l}\text { Clearing heat, } \\
\text { resolving qi- } \\
\text { stagnation }\end{array}$ & \\
\hline Celery & $\begin{array}{l}\text { Leaf of Apium } \\
\text { graveolens L. } \\
\text { (Umbeliferae) }\end{array}$ & Bitter & Cool & Clearing heat & \\
\hline Turmeric & $\begin{array}{l}\text { Rhizome of Curcuma } \\
\text { longa L. (Zingiberaceae) }\end{array}$ & $\begin{array}{l}\text { Bitter, } \\
\text { Spicy }\end{array}$ & Warm & Clearing heat & 22 \\
\hline Burdoc & $\begin{array}{l}\text { Root of Arctium lappa } \mathrm{L} \text {. } \\
\text { (Compositae) }\end{array}$ & $\begin{array}{l}\text { Bitter, } \\
\text { Spicy }\end{array}$ & Cold & $\begin{array}{l}\text { Promoting } \\
\text { defecation }\end{array}$ & \\
\hline Lettuce & $\begin{array}{l}\text { Leaf of Lactuca sativa } \mathrm{L} \text {. } \\
\text { (Compositae) }\end{array}$ & $\begin{array}{l}\text { Bitter, } \\
\text { Sweet }\end{array}$ & Cool & Clearing heat & \\
\hline $\begin{array}{l}\text { Chrysanthemu } \\
\text { m Flower }\end{array}$ & $\begin{array}{l}\text { Flower of } \\
\text { Chrysanthemum indicum } \\
\text { L. or } \\
\text { C. boreale Makino } \\
\text { (Compositae) }\end{array}$ & $\begin{array}{l}\text { Bitter, } \\
\text { Sweet }\end{array}$ & Cool & $\begin{array}{l}\text { Clearing heat, } \\
\text { resolving the } \\
\text { exterior }\end{array}$ & 24 \\
\hline $\begin{array}{l}\text { Japanese } \\
\text { mugwort }\end{array}$ & $\begin{array}{l}\text { Leaf of Artemisia } \\
\text { princeps Pampan. } \\
\text { (Compositae) }\end{array}$ & $\begin{array}{l}\text { Bitter, } \\
\text { Spicy }\end{array}$ & Warm & Hemostasis & \\
\hline Green tea & $\begin{array}{l}\text { Leaf of Camellia } \\
\text { sinensis O. Kuntze } \\
\text { (Theaceae) }\end{array}$ & Bitter & Cool & Clearing heat & 23 \\
\hline Pu-erh tea & $\begin{array}{l}\text { Leaf of Camellia } \\
\text { sinensis O. Kuntze } \\
\text { (Theaceae) }\end{array}$ & Bitter & Cool & $\begin{array}{l}\text { Removing } \\
\text { dampness }\end{array}$ & \\
\hline
\end{tabular}




\section{Anti-inflammatory constituents in the foods with bitter taste}

Table 4 shows the main foods with bitter taste [17]. Some bitter foods and crude drugs are often cold and cool in property. Among bitter crude drugs in Table 4, we studied the NO-suppressing constituents of bitter melon and asparagus. The botanical name of bitter melon is Momordica charantia L. (Cucurbitaceae). The property of bitter melon is cold, the taste is bitter, and the pharmacological function is clearing heat, strengthening the stomach and treating hypoglycemia $[14,16]$. As constituents of bitter melon fruit, momordicin I, charanthin, cucurbitacin, and so forth have been reported $[18,19]$. Ethanolic extract of the fruit of bitter melon showed marked inhibition of NO production [20]. The botanical name of asparagus is Asparagus officinalis L. (Liliaceae). The property of asparagus is Cool, the taste is Sweet and Bitter, and the pharmacological function is nourish yin (Jiin in Japanese) and relieving cough [14, 17]. The standardized extract of Asparagus officinalis stem (ETAS ${ }^{\circledR} 50$, trademark of Amino Up Co., Ltd., Sapporo, Japan) and its constituents, $(S)$-asfural and 5-hydroxymethyl-2-furfural showed marked inhibition of NO production [21]. Besides these, there are reports on anti-inflammatory constituents from bitter foods. Ukil et al. reported curcumin as an anti-inflammatory constituent of turmeric [22]. Wang et al. reported theanine as an anti-inflammatory constituent of green tea [23]. Furthermore, cisspiroketalenolether polyyne and luteolin have been reported to have anti-inflammatory components of chrysanthemum by Yoshikawa et al. [24]. Based on these facts, it was confirmed that anti-inflammatory components were contained in many bitter tasting medicines and foods.

\section{Anti-inflammatory constituents in the foods with Spicy Taste}

The many pungent constituents from foods have been reported to have anti-inflammatory effect. Ginger, red pepper, black pepper are known to contain pungent constituents such as [6]-gingerol, capsaicin, piperine, respectively. Liang et al. [25], Kin et al. [26], Zhai et al. [27] reported that [6]-gingerol, capsaicin, piperine have anti-inflammatory effects, respectively. Furthermore, garlic, black mustard, moringa, and broccoli are known to contain pungent constituents, such as alliin, sinigrin, $\quad 4-[(2$ '- $O$-acetyl- $\alpha$-L-rhamnosyloxy)-benzyl]-isothiocyanate, and sulforaphane, respectively. Hall et al. [28], Lee et al. [29], Park et al. [30] and Townsend et al. [31] reported that alliin, sinigrin, 4-[(2'-O-acetyl- $\alpha$-L-rhamnosyloxy)-benzyl]-isothiocyanate and sulforaphane all have anti-inflammatory effects. These reports suggest that some spicy crude drugs and foods have anti-inflammatory effects. Table 5 shows the main spicy crude drugs and foods with those function.

Among spicy crude drugs and foods in Table 5, we studied the NO-suppressing constituents of green perilla and saposhnikovia root and rhizome. Green perilla is the leaves and branches of Pellira frutescens Britton var. crispa f. viridis (Labiatae). The property of green perilla is warm, and the taste is spicy [16] with pharmacological effects of anti-allergy [32] and anti-inflammation [33]. 
Table 5. Main Spicy crude drugs and those function

\begin{tabular}{|c|c|c|c|c|c|}
\hline $\begin{array}{l}\text { Crude drugs } \\
\text { and foods }\end{array}$ & Origin (family) & Property & Taste & $\begin{array}{l}\text { Pharmacological } \\
\text { Function }\end{array}$ & Reference \\
\hline Pueraria Root & $\begin{array}{l}\text { Root of Pueraria lobata } \\
\text { Ohwi (Legminosae) }\end{array}$ & Plane & $\begin{array}{l}\text { Spicy, } \\
\text { Sweet }\end{array}$ & & 37 \\
\hline $\begin{array}{l}\text { Cinnamon } \\
\text { Bark }\end{array}$ & $\begin{array}{l}\text { Bark of Cinnamomum cassia } \\
\text { Blume (Lauraceae) }\end{array}$ & Warm & $\begin{array}{l}\text { Spicy, } \\
\text { Sweet }\end{array}$ & & 38 \\
\hline $\begin{array}{l}\text { Asiasarum } \\
\text { Root }\end{array}$ & $\begin{array}{l}\text { Root and Rhizome of } \\
\text { Asiasarum sieboldii } \mathrm{F} \text {. } \\
\text { Maekawa or A. } \\
\text { heterotropoides } \mathrm{F} \text {. Maekawa } \\
\text { var. mandshuricum } \mathrm{F} \text {. } \\
\text { Maekawa (Aristolochiaceae) }\end{array}$ & Warm & Spicy & & \\
\hline $\begin{array}{l}\text { Ginger } \\
\text { Rhizome }\end{array}$ & $\begin{array}{l}\text { Rhizome of Zingiber } \\
\text { officinale Roscoe } \\
\text { (Zingiberaceae) }\end{array}$ & Warm & Spicy & $\begin{array}{l}\text { Resolving the } \\
\text { exterior (Enamate } \\
\text { pathogen at } \\
\text { exterior location) }\end{array}$ & 25,36 \\
\hline Ephedra Herb & $\begin{array}{l}\text { Stem of Ephedra sinica } \\
\text { Stapf or E. intermedia } \\
\text { Schrenk et C.A. Meyer, or E. } \\
\text { equisetina Bunge } \\
\text { (Ephedraceae) }\end{array}$ & Warm & $\begin{array}{l}\text { Spicy, } \\
\text { Bitter }\end{array}$ & & \\
\hline $\begin{array}{l}\text { Saposhnikovia } \\
\text { Root and } \\
\text { Rhizome }\end{array}$ & $\begin{array}{l}\text { Root and Rhizome of } \\
\text { Saposhnikovia divaricata } \\
\text { Schischkin (Umbelliferae) }\end{array}$ & Warm & $\begin{array}{l}\text { Spicy, } \\
\text { Sweet }\end{array}$ & & 35 \\
\hline Mentha Herb & $\begin{array}{l}\text { Aerial part of Mentha } \\
\text { arvensis L. var. piperascens } \\
\text { Malinvaud (Lamiaceae) }\end{array}$ & Cool & Spicy & & \\
\hline Perilla Herb & $\begin{array}{l}\text { Leaf and branch of Perilla } \\
\text { frutescens Britton var. acuta } \\
\text { Kudo or } P \text {. frutescens } \\
\text { Britton var. crispa Decaisne } \\
\text { (Lamiaceae) }\end{array}$ & Warm & Spicy & $\begin{array}{l}\text { Resolving the } \\
\text { exterior, } \\
\text { Reinforcing qi }\end{array}$ & 33 \\
\hline $\begin{array}{l}\text { Green perilla } \\
\text { Herb }\end{array}$ & $\begin{array}{l}\text { Leaf and branch of Perilla } \\
\text { frutescens (L.) Britton var. } \\
\text { crispa } \mathrm{f} \text {. viridis Makino } \\
\text { (Lamiaceae) }\end{array}$ & Warm & Spicy & $\begin{array}{l}\text { Resolving the } \\
\text { exterior, } \\
\text { Reinforcing qi }\end{array}$ & 34 \\
\hline $\begin{array}{l}\text { Citrus Unshiu } \\
\text { Peel }\end{array}$ & $\begin{array}{l}\text { Peel of Citrus unshiu } \\
\text { Markowicz or } C \text {. reticulata } \\
\text { Blanco (Rutaceae) }\end{array}$ & Warm & $\begin{array}{l}\text { Spicy, } \\
\text { Bitter }\end{array}$ & $\begin{array}{l}\text { Regulating qi- } \\
\text { flowing }\end{array}$ & \\
\hline $\begin{array}{l}\text { Magnolia } \\
\text { Bark }\end{array}$ & $\begin{array}{l}\text { Bark of Magnolia obovata } \\
\text { Thunberg, M. officinalis } \\
\text { Rehder et Wilson or } M \text {. } \\
\text { officinalis Rehder et Wilson } \\
\text { var. biloba Rehder et Wilson } \\
\text { (Magnoliaceae) }\end{array}$ & Warm & $\begin{array}{l}\text { Spicy, } \\
\text { Bitter }\end{array}$ & $\begin{array}{l}\text { Regulating qi- } \\
\text { flowing }\end{array}$ & \\
\hline $\begin{array}{l}\text { Japanese } \\
\text { Zanthoxylum } \\
\text { Peel }\end{array}$ & $\begin{array}{l}\text { Peel of Zanthoxylum } \\
\text { piperitum De Candolle } \\
\text { (Rutaceae) }\end{array}$ & Warm & Spicy & $\begin{array}{l}\text { Warming spleen } \\
\text { and stomach for } \\
\text { dispelling Cold }\end{array}$ & 26 \\
\hline
\end{tabular}


A green perilla water extract was fractionated by the liquid - liquid separation method using ethyl acetate, $n$-butanol, and water [8]. The ethyl acetate-soluble part remarkably suppressed NO production induced by interleukin (IL)-1 $\beta$ in the hepatocytes. Shisoflavanone A, 5,8-dihydroxy7-methoxy-flavanone, negletin, luteolin, apigenin, and rosmarinic acid were isolated as the NOsuppressing constituents from the ethyl acetate-soluble fraction of green perilla extract [34]. Saposhnikovia root and rhizome are the root and rhizome of Saposhnikovia divaricata Schischkin (Umbelliferae)and have spicy and sweet tastes. 3'-O-Angeloylhamaudol, hamaudol and ledebouriellol were isolated from saposhnikovia root and rhizome as the NO-suppressing constituents [35] (Figure 3).

The NO production-suppressing constituents were also isolated from hard herbal medicines. Hong et al. reported that the constituents in ginger extracts, such as [6]-shogaol, which suppressed NO production in macrophage cells [36]. Hu et al. isolated puerarin, a constituent to suppress NO production, from Pueraria Root [37]. He et al. reported such constituents in Cinnamon Bark: (+)threo-(7S,8R)-guaiacylglycerol- $\beta$-coniferyl aldehyde ether and (+)-erythro-(7S,8S)guaiacylglycerol- $\beta$-coniferyl aldehyde ether [38].
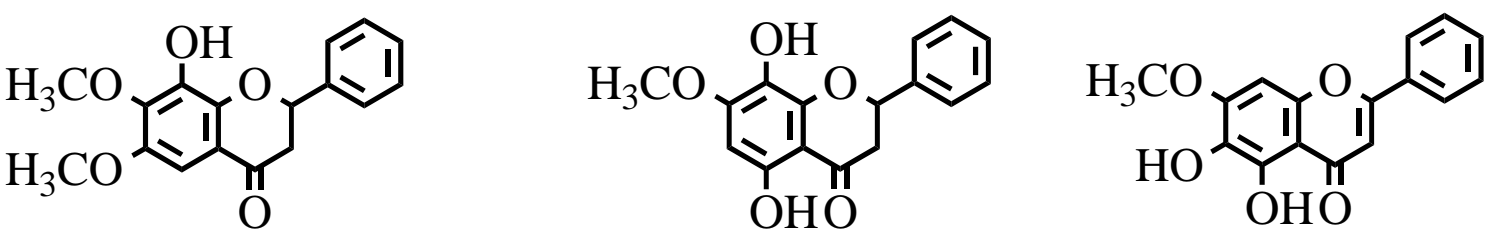

Shisoflavanone A (racemic) 5,8-Dihydroxy-7-methoxyflavanone (racemic) Negletein<smiles>O=c1cc(-c2ccc(O)c(O)c2)oc2cc(O)cc(O)c12</smiles>

Luteolin<smiles>C/C=C(/C)C(=O)O[C@H]1Oc2cc3oc(C)cc(=O)c3c(O)c2CC1(C)C</smiles>

3'-O-Angeloylhamaudol<smiles>O=c1cc(-c2ccc(O)cc2)oc2cc(O)cc(O)c12</smiles>

Apigenin<smiles>Cc1cc(=O)c2c(O)c3c(cc2o1)O[C@H](O)C(C)(C)C3</smiles>

Hamaudol<smiles>O=C(/C=C/c1ccc(O)c(O)c1)O[C@H](Cc1ccc(O)c(O)c1)C(=O)O</smiles>

Rosmarinic acid<smiles>C/C=C(/C)C(=O)O[C@H]1Oc2cc3oc(CO)cc(=O)c3c(O)c2CC1(C)C</smiles>

Ledebouriellol

Figure 3. NO-suppressing constituents in the crude drugs with spicy taste. Shisoflavanone A, 5,8Dihydroxy-7-methoxyflavanone, negletin, luteolin, apigenin are flavonoids. Rosmarinic acid is a phenylpropanoid, and 3'-O-angeloylhamaudol, hamaudol, and ledebouriellol are chromons. 


\section{CONCLUSION}

We have investigated anti-inflammatory constituents in crude drugs and foods by monitoring NO production in the hepatocytes. We speculated that anti-inflammatory constituents are included in the crude drugs and foods with cold or cool property or those with bitter or spicy taste. Indeed, we found many anti-inflammatory constituents of six crude drugs and two foods. In the advancement of Kampo medicine, crude drugs and foods with cold or cool properties and with bitter taste include anti-inflammatory constituents, which have pharmacological functions of clearing heat, resolving qi-stagination, and resolving the exterior to maintain internal balance.

\section{EXPERIMENTAL}

\section{Materials and Methods}

Active constituents were extracted by hot water or methanol and separated from crude drugs and foods. Hot-water extraction (decoction) was often used to prepare Kampo medicine. Then, the extract was fractionated by hydrophobicity into three crude fractions, including ethyl acetatesoluble, $n$-butanol-soluble, and water-soluble fractions. These fractions were purified by silica gel chromatography, thin-layer chromatography, or high-performance liquid chromatography to purify constituents. Their chemical structures were determined by nuclear magnetic resonance and mass spectra analyses. Details on the identification and quantification of the compounds used in the pharmacological assays are described in the references of Table 6.

Table 6. Compounds isolated in our studies and other studies.

\begin{tabular}{|l|l|l|}
\hline \multicolumn{1}{|c|}{ Crude drugs or foods } & \multicolumn{1}{|c|}{ Compounds } & Reference \\
\hline Coptis Rhizome & Berberine & 7 \\
\hline Phellodendron Bark & Brberine, limonin, obakunone & 7 \\
\hline Lonicera Flower & Chlorogenic acid & 8 \\
\hline Cherry Bark & Sakuranetin, naringenin & 9 \\
\hline Atractylodes lancea Rhizome & $(2 E, 8 R$-Decene-4,6-diyne-1,8-diol-8- $O-\beta$ - & 15 \\
& D-glucopyranoside & \\
\hline Asparagus & S]-Asfural, 5-hydroxymethyl-2-furfural & 21 \\
\hline Green perilla Herb & Shisoflavanone A, negletin, luteolin, & 34 \\
& 5,8-dihydroxy-7-methoxyflavanone, & \\
& apigenin, rosmarinic acid & \\
\hline $\begin{array}{l}\text { Saposhnikovia Root and } \\
\text { Rhizome }\end{array}$ & 3'-O-Angeloylhamaudol, hamaudol, & 35 \\
\hline Scutellaria Root & ledebouriellol & \\
\hline Gardenia Fruit & Baicalin, baicalein, wogonin, oroxylin A & 10,11 \\
\hline Moutan Bark & Genipin, crocetin & 12,13 \\
\hline Bitter melon & Paeonol & 16 \\
\hline
\end{tabular}




\begin{tabular}{|l|l|l|}
\hline Turmeric & Curcumin & 22 \\
\hline Green tea & Theanine & 23 \\
\hline Chrysanthemum Flower & cis-Spiroketalenolether polyyne & 24 \\
\hline Ginger Rhizome & {$[6]$-Gingerol, [6]-shogaol } & 25,36 \\
\hline Pueraria Root & Puerarin & 37 \\
\hline Cinnamon Bark & $\begin{array}{l}\text { (+)-threo-(7S,8R)-Guaiacylglycerol- } \beta \text { - } \\
\text { coniferyl aldehyde ether and (+)-erythro- } \\
\text { (7S,8S)-guaiacylglycerol- } \beta \text {-coniferyl }\end{array}$ & 38 \\
& $\begin{array}{l}\text { aldehyde ether } \\
\end{array}$ & \\
&
\end{tabular}

\section{In vitro evaluation of anti-inflammatory effects}

Anti-inflammatory effects were examined by monitoring the production of pro-inflammatory mediators. Primary cultured rat hepatocytes produce pro-inflammatory mediators, such as NO, pro-inflammatory cytokines, and chemokines in the presence of IL-1 $\beta[39,40]$. The constituents isolated from crude drugs or foods were analyzed by these methods to measure the expression of the pro-inflammatory mediators in the hepatocytes. These mediators were detected by enzymelinked immunosorbent assay and western blot analysis [for example, 40], and their mRNA levels were measured by reverse transcription-polymerase chain reaction. To compare antiinflammatory potencies of crude drugs or foods, or their constituent, half-maximal inhibitory concentrations were calculated.

\section{GLOSSARY}

Blood: The "red fluid" flowing through the body carrying nutrients and maintaining life. A concept based on Kampo medicine.

Five elements theory: A basic concept of an ancient Chinese medicine. All matter consists of five elements; i.e., wood, fire, earth, metal, and water.

Five tastes: Sour, bitter, sweet, spicy, and salty. Categories of tastes are classified by the ancient Chinese yin-yang theory.

Four properties: Cold, cool, warm, and heat. Categories of properties are classified by the ancient Chinese yin-yang theory.

Gehyo (Japanese): Resolving the exterior to emanate pathogens at exterior location with spicy and warm or cool natured drugs.

Jiin (Japanese): To nourish yin by the supplementation of body fluids.

Kampo medicine: Traditional Japanese medicine based on traditional Chinese medicine, which was brought to Japan in the 5th and 6th centuries. Kampo Medicine was independently developed in Japan in the 18th century.

Kiutu (Japanese): Qi-stagnation. An example of pathological conditions of qi. 
Qi: The fundamental energy that carries out living activities. A concept based on Kampo medicine and traditional Chinese medicine.

Qi, Blood, and Water: Three constituent elements or categories of the human body in Kampo medicine and traditional Chinese medicine.

Traditional Chinese medicine: Medicine to treat diseases using plant-based natural products, whose prototype was born in ancient China about 3,000 years ago.

Water: The "colorless fluid" flowing through the body carrying nutrients and maintaining life.

Yakuno (Japanese): The pharmacological functions of crude drugs in Kampo medicine.

Yin-yang theory: The basic concept of ancient Chinese medicine, which everything in the universe is classified into two categories, yin and yang. For example, heat and cold, day and night, and man and woman.

Abbreviations: NO, nitric oxide; IL, interleukin.

Acknowledgments and Funding: We thank Prof. Tadayoshi Okumura and Dr. Tetsuya Okuyama for kind advice. This work was supported in part by research grants from the AsiaJapan Research Institute of Ritsumeikan Asia-Japan Research Organization, Ritsumeikan University (Ibaraki, Osaka, Japan) and the Amino Up Co., Ltd. (Sapporo, Japan).

Authors' Contributions: All authors contributed to this review.

Competing Interests: None declared.

\section{REFERENCES}

1. Sago M: Yokuwakaru Koutei Daikei No Kihon To Sikumi [In Japanese]. Tokyo: Shuwa System; 2008: 188.

2. Chang SL: Chinese herbal medicine including historical aspects. Edited by Inui A: Springer Science \& Business Media; 2016:1-7.

3. Kim S: Kiso Karano Kampoyaku [in Japanese] ( $3^{\text {rd }}$ ed.). Tokyo: Yakuji Nippo; 2012: 46-200.

4. Yoshigai E, Hara T, Inaba H, Hashimoto I, Tanaka Y, Kaibori M, Kimura T, Okumura T, Kwon $\mathrm{AH}$, Nishizawa M: Interleukin-1 $\beta$ induces tumor necrosis factor- $\alpha$ secretion from rat hepatocytes. Hepatol Res 2014, 44:571-583.

5. Inaba H, Yoshigai E, Okuyama $\mathrm{T}$, Murakoshi M, Sugiyama K, Nishino H, Nishizawa M: Antipyretic analgesic drugs have different mechanisms for regulation of the expression of inducible nitric oxide synthase in hepatocytes and macrophages. Nitric Oxide 2015, 44:61-70.

6. Tanemoto R, Okuyama T, Matsuo H, Okumura T, Ikeya Y, Nishizawa M: The constituents of licorice (Glycyrrhiza uralensis) differentially suppress nitric oxide production in interleukin1 $\beta$-treated hepatocytes. Biochem Biophys Rep 2015, 2:153-159. 
7. Fujii A, Okuyama T, Wakame K, Okumura T, Ikeya Y, Nishizawa M: Identification of antiinflammatory constituents in Phellodendri Cortex and Coptidis Rhizoma by monitoring the suppression of nitric oxide production. J Nat Med 2017, 71:745-756.

8. Ohno N, Yoshigai E, Okuyama T, Yamamoto Y, Okumura T, Sato K, Ikeya Y, Nishizawa M: Chlorogenic acid from the Japanese herbal medicine Kinginka (Flos Lonicerae japonicae) suppresses the expression of inducible nitric oxide synthase in rat hepatocytes. HOAJ Biol 2012, $1: 1-10$.

9. Yamauchi Y, Okuyama T, Ishii T, Okumura T, Ikeya Y, Nishizawa M: Sakuranetin downregulates inducible nitric oxide synthase expression by affecting interleukin-1receptor and CCAAT/enhancer-binding protein $\beta$. J Nat Med 2018. https://doi.org/10.1007/s11418-0181267-x.

10. Huang $\mathrm{WH}$, eLee $\mathrm{AR}$, Yang $\mathrm{CH}$ : Antioxidative and anti-inflammatory activities of polyhydroxyflavonoids of Scutellaria baicalensis Georgi. Biosci Biotechnol Biochem 2006, 70:2371-2380.

11. Chen C, Zhang C, Cai L, Xie H, Hu W, Wang T, Lu D, Chen H: Baicalin suppresses IL-1ßinduced expression of inflammatory cytokines via blocking NF- $\mathrm{KB}$ in human osteoarthritis chondrocytes and shows protective effect in mice osteoarthritis models. Int Immunopharmacol 2017, 52:218-226.

12. Ko JW, Shin NR, Park SH, Cho YK, Kim JC, Seo CS, Shin IS: Genipin inhibits allergic responses in ovalbumin-induced asthmatic mice. Int Immunopharmacol 2017, 53:49-55.

13. Hong YJ, Yang KS: Anti-inflammatory activities of crocetin derivatives from Gardenia jasminoides. Arch Pharm Res 2013, 36:933-940.

14. Minar Y, Tokui N, Fukumoto A, Zhu GS, Guo X, Sugahara T: The classification of dietic Chinese drugs for cooking Chinese medicated diet. Journal for the Integrated Study of Dietary Habits 2000, 11:277-287.

15. Xu K, Feng ZM, Yang YN, Jiang JS, Zhang PC: Four new C10-polyacetylene glycosides from the rhizomes of Atractylodes lancea. J Asian Nat Res 2017, 19:121-127.

16. Lou Y, Wang C, Tang Q, Zheng W, Feng Z, Yu X, Guo X, Wang J: Paeonol inhibits IL-1 $\beta$ induced inflammation via PI3K/Akt/NF-kB pathways: in vivo and vitro studies. Inflammation 2017, 40:1698-1706.

17. Nemoto Y: Daidokoro Kampo [In Japanese]. Tokyo: Ikeda Shoten; 2017: 45-134.

18. Liu H, Wang GC, Zhang MX, Ling B: The cytotoxicology of momordicins I and II on Spodoptera Litura cultured cell line SL-1. Pestic Biochem Physiol 2015, 122:110-118. 
19. Desai S, Takte P: Charantin: An important lead compound from Momordica charantia for the treatment of diabetes. Journal of Pharmacognosy and Phytochemistry 2015, 3: 163-166.

20. Lii CK, Chen HW, Yun WT, Liu KL: Suppressive effects of wild bitter gourd (Momordica charantia Linn. var. abbreviata ser.) fruit extracts on inflammatory responses in RAW264.7 macrophages. J Ethnopharmacol 2009, 122:227-233.

21. Nishizawa M, Kano M, Okuyama T, Okumura T, Ikeya Y: Anti-inflammatory effects of enzyme-treated asparagus extract and its constituents in hepatocytes. Functional Foods in Health and Disease 2016, 6:91-109.

22. Ukil A, Maity S, Karmakar S, Datta N, Vedasiromoni JR, Das PK: ICurcumin, the major component of food flavor turmeric, reduce muscosal injury in trinitrobenzene sulphonic acidinduced colitis. Br J Pharmacol 2003, 139:209-218.

23. Wang D, Gao Q, Wang T, Qian F, Wang Y: Theanine: the unique amino acid in the tea plant as an oral hepatoprotective agent. Asia Pac J Clin Nutr 2017, 26:384-391.

24. Yoshikawa M, Morikawa T, Toguchida I, Harima S, Matsuda H: Medicinal Flowers. II. Inhibitors of nitric oxide production and absolute stereostructures of five new germacrane-type sesquiterpenes, kikkanols D, D monoacetate, E, F, and F monoacetate from the flowers of Chrysanthemum indicum L. Chem Pharm Bull. 48 2000:651-656.

25. Liang N, Sang Y, Liu W, Yu W, Wang X: Anti-inflammatory effects of gingerol on lipopolysaccharide-stimulated RAW 264.7 cells by inhibiting NF- $\mathrm{kB}$ signaling pathway. Inflammation 2018, 41:835-845.

26. Kim CS, Kawada T, Kim BS, Han IS, Choe SY, Kurata T, Yu R: Capsaicin exhibits antiinflammatory property by inhibiting IкB- $\alpha$ degradation in LPS-stimulated peritoneal macrophages. Cellular Signalling 2003, 15:299-306.

27. Zhai WJ, Zhang ZB, Xu NN, Guo YF, Qiu C, Li CY, Deng GZ, Guo MY: Piperine plays an anti-inflammatory role in Staphylococcus aureus Endometritis by inhibiting activation of NFкB and MAPK pathways in mice. Evid Based Complement Alternat Med 2016:8597208.

28. Hall A, Troupin A, Londono-Renteria B, Colpitts TM: Garlic organosulfur compounds reduce inflammation and oxidative stress during Dengue virus infection. Viruses 2017, 9:159.

29. Lee HW, Lee CG, Rhee DK, Um SH, Pyo S: Sinigrin inhibits production of inflammatory mediators by suppressing NF- $\kappa$ B/MAPK pathways or NLRP3 inflammasome activation in macrophages. Int Immnopharmacol 2017, 45:163-173.

30. Park EJ, Cheenpracha S, Chang LC, Kondratyuk TP, Pezzuto JM: Inhibition of lipopolysaccharide-induced cyclooxygenase-2 expression and inducible nitric oxide synthase 
by $4-\left[\left(2^{\prime}-O\right.\right.$-acetyl- $\alpha$-L-rhamnosyloxy)benzyl]isothiocyanate from Moringa oleifera. Nutr Cancer 2011, 63:971-982.

31. Townsend BE, Johnson RW: Sulforaphane reduces lipopolysaccharide-induced proinflammatory markers in hippocampus and liver but does not improve sickness behavior. Nutr Neurosci 2017, 20:195-202.

32. Ueda H, Yamazaki M: Anti-inflammatory and anti-allergic actions by oral administration of a perilla leaf extract in mice. Biosci Biotechn Biochem 2001, 65:1673-1675.

33. Banno N, Akihisa T, Tokuda H, Yasukawa K, Higashihara H, Ukiya M, Watanabe K, Kimura Y, Hasegawa J, Nishino H: Triterpene acids from the leaves of Perilla frutescence and their anti-inflammatory and antitumor-promoting effect. Biosci Biotechn Biochem 2004, 68:85-90.

34. Nakajima A,Yamamoto Y, Yoshinaka N, Namba M, Matsuo H, Okuyama T, Yoshigai E, Okumura T, Nishizawa M, Ikeya Y: A new flavanone from green perilla inhibits NO production. Biosci Biotechnol Biochem 2015, 79:138-146.

35. Kamino T, Shimokura T, Morita Y, Tezuka Y, Nishizawa M, Tanaka K: Comparative analysis of the constituents in Saposhnikoviae Radix and Glehnia Radix cum Rhizoma by monitoring inhibitory activity of nitric oxide production. J Nat Med 2016, 70:253-259.

36. Hong SS, Oh JS: Phenylpropanoid ester from Zingiber officinale and their inhibitory effects on the production of nitric oxide. Arch Pharm Res 2012, 35:315-320.

37. Hu W, Yang X, Zhe C, Zhang Q, Sun L, Cao K: Puerarin inhibits iNOS, COX-2 and CRP expression via suppression of NF- $\mathrm{kB}$ activation in LPS-induced RAW264.7 macrophage cells. Pharmacol Rep 2011, 63:781-789.

38. He S, Zeng KW, Jiang Y, Tu PF: Nitric oxide inhibitory constituents from the barks of Cinnamomum cassia. Fitoterapia 2016, 112:153-160.

39. Yoshigai E, Hara T, Inaba H, Hashimoto I, Tanaka Y, Kaibori M, Kimura T, Okumura T, Kwon $\mathrm{AH}$, Nishizawa M: Interleukin-1 $\beta$ induces tumor necrosis factor- $\alpha$ secretion from rat hepatocytes. Hepatol Res 2014, 44:571-583.

40. Inaba H, Yoshigai E, Okuyama T, Murakoshi M, Sugiyama K, Nishino H, Nishizawa M: Antipyretic analgesic drugs have different mechanisms for regulation of the expression of inducible nitric oxide synthase in hepatocytes and macrophages. Nitric Oxide 2015, 44:61-70. 